\title{
Reconsidering the Age and Typological Character of "Pox Pottery" from Guerrero, Mexico
}

\author{
Douglas J. Kennett (D), Barbara Voorhies (D), and Josue Gomez
}

\begin{abstract}
We revisit the age and typological character of "Pox Pottery" that was reported in the 1960s by Charles Brush who considered it to be uniquely early ( 2440 BC). Investigating the same two sites in coastal Guerrero where Brush excavated, we recovered Early Formative ceramics, some with the "pox" attribute. Here, we report potsherd frequencies for these deposits at both sites according to regional ceramic typologies, as well as $\mathrm{AMS}{ }^{14} \mathrm{C}$ dates used to establish a Bayesian stratigraphic chronology for each site to better constrain the age of these Early Formative period deposits. We argue that "Pox Pottery" is not a ceramic type per se and that the "pox" attribute occurs in multiple Early Formative period ceramic types. The earliest pottery is similar to other Red-on-Buff ceramic traditions from the Central Mexican Highlands and west of the Isthmus of Tehuantepec. Our chronological work demonstrates that these ceramics date between 1820 and 1400 cal BC, consistent with other recent studies indicating an early age of Red-on-Buff ceramics and suggesting shared cultural traditions distinct from the contemporary Locona interaction sphere that emerged in parallel.
\end{abstract}

Keywords: Mesoamerica, Western Mexico, Early Formative period, Mexico's Pacific Coast, radiocarbon dating, stratigraphic Bayesian chronology, Red-on-Buff ceramics

Revisamos la antigüedad y el carácter tipológico de la cerámica conocida como "Pox Pottery". Ésta fue descrita con base en un atributo específico reportado en la década de 1960 por Charles Brush, quien lo consideró particularmente temprano ( 2440 aC). Excavaciones en los mismos sitios de la costa de Guerrero donde Brush trabajó permitieron recuperar cerámica del periodo Formativo Temprano y mostraba las características "pox". Aquí reportamos las frecuencias de fragmentos cerámicos de esos depósitos, de acuerdo con las tipologías regionales establecidas, y reportamos fechas radiométricas $\left(A M S{ }^{14} C\right)$ usadas para establecer una cronología estratigráfica Bayesiana para delimitar la edad de los depósitos en cada sitio. Proponemos que "Pox Pottery" no corresponde con un tipo cerámico per se, y que el atributo "pox" ocurre en varios tipos cerámicos del Formativo Temprano. Ésta es similar a las tradiciones rojo sobre bayo que se desarrollaron temprano en las tierras altas del centro de México y al occidente del Istmo de Tehuantepec. Nuestro refinamiento cronológico demuestra que esta cerámica data entre 1820 y 1400 cal aC. Es consistente con estudios recientes que indican una edad similar para las cerámicas rojo sobre bayo, sugiriendo la existencia de tradiciones culturales diferentes al complejo Locona que emergió paralelamente.

Palabras clave: Mesoamerica, México occidental, Formativo Temprano, Costa del Pacífico de México, fechas radiométricas, cronología estratigráfica Bayesiana, las cerámicas rojo sobre bayo

$\mathrm{M}$ ore than 50 years ago archaeologist Charles E. Brush (1965) published a report in Science about what he thought was the earliest known pottery from Mexico, which he had discovered at two archaeological sites in coastal Guerrero: Puerto
Marqués and La Zanja (Figure 1). Brush described this pottery as friable, with distinctive interior surfaces characterized by small pits and gouges. He thought the surface treatment originated during production from wiping vessel interiors before the clay was almost dry, causing

Douglas J. Kennett and Barbara Voorhies a Department of Anthropology, University of California-Santa Barbara, Campus Code 3210, Santa Barbara, CA 93106-3210, USA (kennett@anth.ucsb.edu, corresponding author)

Josue Gomez $\square$ Department of Archaeology, University of Western Australia, 35 Stirling Hwy, Crawley WA 6009, Australia

Latin American Antiquity 32(3), 2021, pp. 503-516

Copyright (C) The Author(s), 2021. Published by Cambridge University Press on behalf of the Society for American Archaeology. This is an Open Access article, distributed under the terms of the Creative Commons Attribution licence (http://creativecommons.org/licenses/by/4.0/), which permits unrestricted re-use, distribution, and reproduction in any medium, provided the original work is properly cited.

doi:10.1017/laq.2021.14 


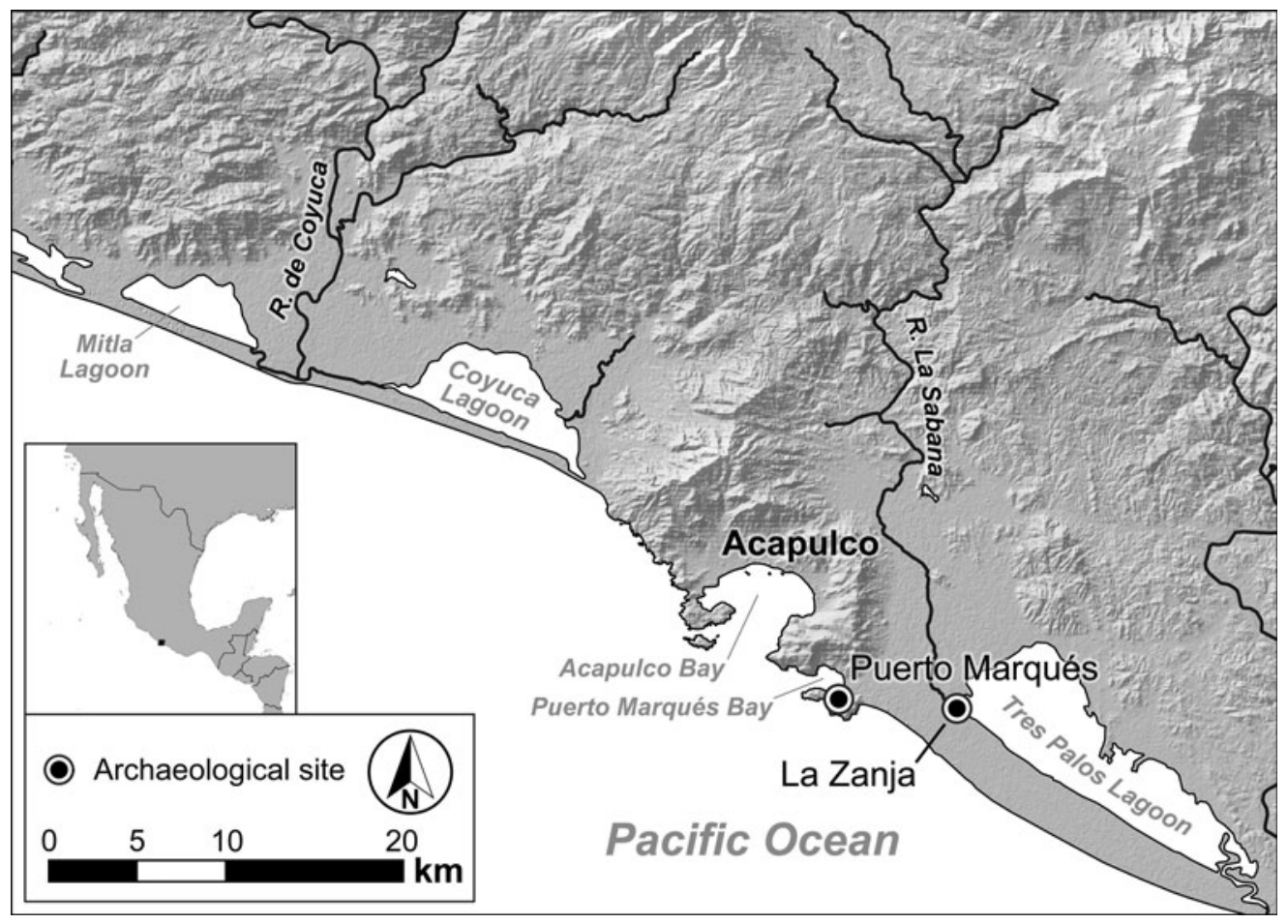

Figure 1. A portion of the Guerrero coastline showing the locations of Puerto Marqués and La Zanja archaeological sites (map drawn by Douglas J. Kennett and digitized by Thomas Harper).

inclusions to be dragged or removed or both. The rough vessel interiors contrasted with the smooth, often red-slipped vessel exterior surfaces (Figure 2). Brush named it "Pox Pottery," argued for an approximate date of $2440 \pm 140$ based on a single radiocarbon date, and noted its similarity to early pottery reported from the Tehuacan Valley in Puebla, Mexico (MacNeish 1964).

During new excavations we conducted at Puerto Marqués and La Zanja, we recovered Early Formative period pottery, some with pitted interior surfaces, in the deepest ceramic-bearing deposits (Voorhies and Kennett 2016). In this article we reevaluate the typological character of "Pox Pottery" and present Bayesian chronologies for Puerto Marqués and La Zanja based on new AMS ${ }^{14} \mathrm{C}$ dates to constrain the age of these Early Formative deposits. Our specific research goal going into the project was not to study "Pox Pottery" but to investigate the cultural transition that took place in coastal Guerrero from the Archaic ( 6000-2000 BC) to Early Formative (2000-600 BC) time periods (Kennett et al. 2008; Voorhies and Kennett 2021).
Previously, archaeologist Rubén Manzanilla López directed a project focusing on Puerto Marqués and its surroundings (Manzanilla López 2000; Manzanilla López et al. 1991:3), but it did not address this particular cultural transition because of a lack of relevant evidence.

\section{The Archaeological Sites}

The Puerto Marqués archaeological site is located on a hillside on the southern margin of Puerto Marqués Bay that overlooks Playa Majahua, a small, narrow sandy beach (Figure 3 ). The site is a poorly defined mound measuring approximately $150 \times$ $130 \mathrm{~m}$ and reaches a height of $22 \mathrm{~m}$ asl (Barba et al. 1989; Manzanilla López et al. 1991:13). We placed our test pit (Unit 1) immediately behind the buildings of a former residence and close to the test pits previously excavated by Manzanilla López (Pozo 1) and Brush. Since Brush's time this area had been terraced, resulting in the removal of about $2.5 \mathrm{~m}$ of the upper archaeological deposits.

The earliest pottery that Brush encountered in his excavation at Puerto Marqués was between 

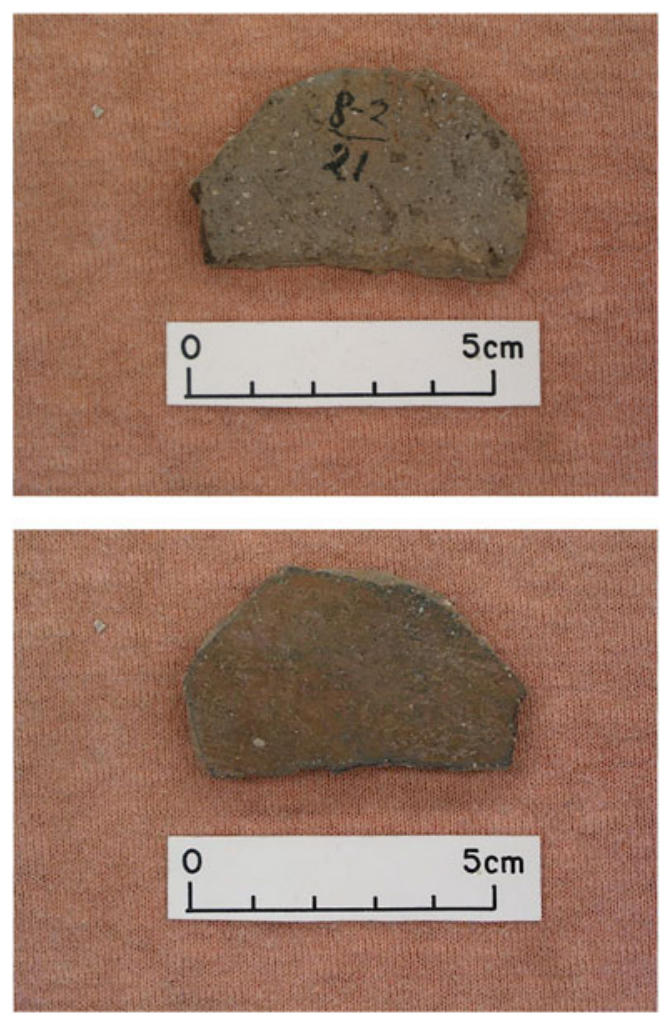

Figure 2. A body sherd from Brush's Pox Pottery collection in the INAH Ceramoteca. Top: Sherd interior. Bottom: Red-slipped sherd exterior (photographs by Barbara Voorhies). (Color online)

$6.00 \mathrm{~m}$ and $6.60 \mathrm{~m}$ below the surface (levels 3133; Brush 1969), immediately overlying aceramic cultural deposits in the lowest excavation levels. In the general Mesoamerican chronology, this pottery falls within the Early Formative period. ${ }^{1}$ The total number of "pox" potsherds that Brush recovered is unclear because of the particular classification method that he used and reported for the ceramic collection. However, he reported that $35 \%(N=189)$ of 547 analyzed body potsherds had the characteristic pitted interior surfaces (Brush 1969:Table 5A and Table 5D). He also reported that he found only five rim sherds from these excavation levels, consequently making assessments of vessel form very difficult (Brush 1969:Table 6).

Our excavation measured $2.0 \times 2.0 \mathrm{~m}$ at the onset and was $\sim 5.40 \mathrm{~m}$ deep (Figure 4), but was stepped down three times: at $3.2 \mathrm{~m}$ when it measured $2.0 \times 1.0 \mathrm{~m}$, at $4.4 \mathrm{~m}$ when it measured
$1.0 \times 1.0 \mathrm{~m}$, and at $5.0 \mathrm{~m}$ when it became only $1.0 \times 0.5 \mathrm{~m}$. We encountered aceramic cultural deposits in the lowest levels, from $4.00 \mathrm{~m}$ to $5.40 \mathrm{~m}$ below the surface, despite the presence of a few potsherds that we considered intrusive. Directly overlying the aceramic strata are the deposits with the earliest potsherds (Stratum 6), including those with the attributes that Brush attributed to "pox."

La Zanja, the second site where Brush found "Pox Pottery," is adjacent to the Tres Palos lagoon, approximately $8 \mathrm{~km}$ southeast of Puerto Marqués and about $5 \mathrm{~km}$ from the ocean. ${ }^{2}$ The site is a single large, low mound (Figure 5) that is approximately 4 ha in area and $3.2 \mathrm{~m}$ high. The Río La Sabana flows along the mound's northern margin, but the remainder of the mound's base is surrounded by marsh. Brush dug two test pits into the mound but found "Pox Pottery" in only one of them: Test Pit 2. There Brush reported 73 "pox" potsherds in the sediment between 3.40 and $\sim 4.30 \mathrm{~m}$ (levels 16-22) below the surface (1969:Figure 6). He terminated the excavations after reaching the water table and before reaching either preceramic strata or culturally sterile strata.

We placed a test pit (Unit 1) near the top of the La Zanja mound based on results of surface collection of cultural material and an exploratory auguring program. The $2 \times 2 \mathrm{~m}$ unit was excavated in $20 \mathrm{~cm}$ levels within cultural strata. The water table was reached at $1.08 \mathrm{~m}$ below the surface, and we resorted to the use of several pumps to continue excavating. Even with groundwater flowing into the unit, the deposits were compact, and we were able to keep stratigraphic control of excavated material.

The bottom of the test pit reached a depth of $3.60 \mathrm{~m}$ below the surface at the end of excavation (Figure 4). The lowest stratum, Stratum VII, is reddish-brown sand that is culturally sterile. It is overlain by Stratum VI, a highly compact deposit with a gray-colored clay matrix that contains Early Formative period pottery, including sherds with pitted interior surfaces.

\section{Ceramic Analysis}

We analyzed the pottery collections from both sites using the type system of ceramic 


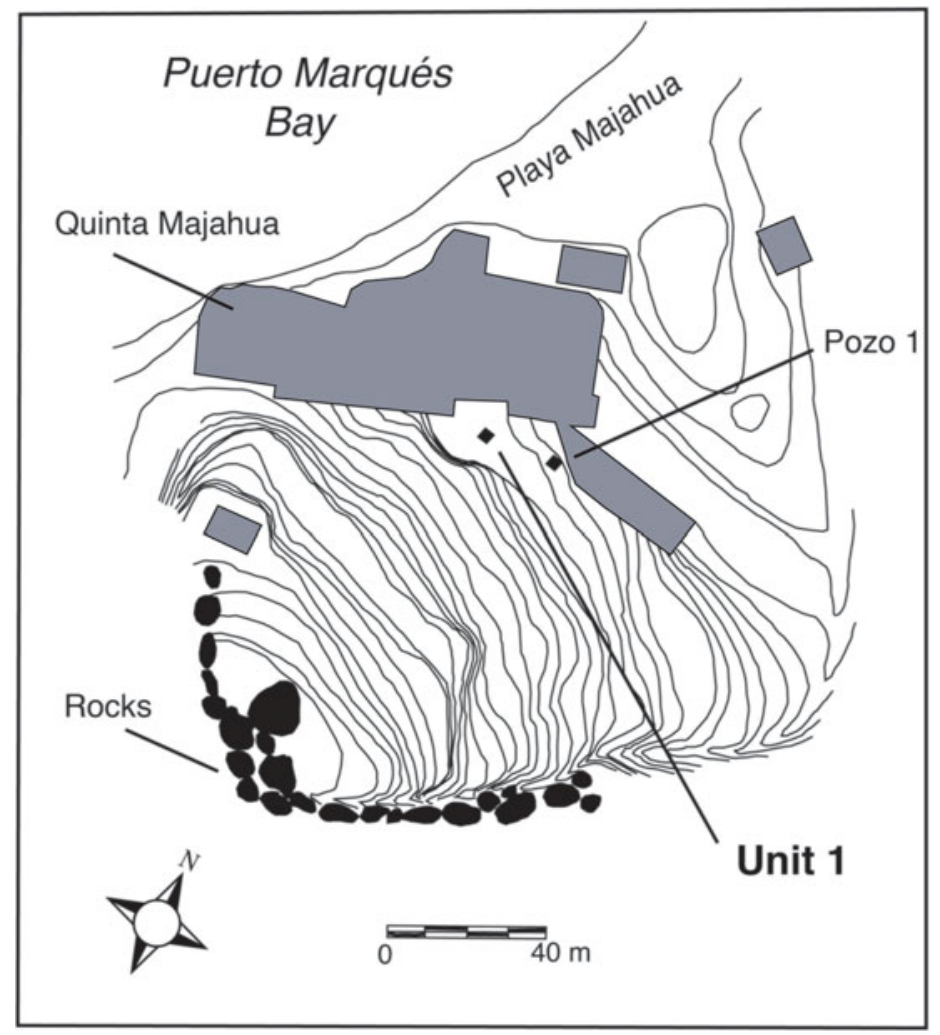

Figure 3. Topographic map of the Puerto Marqués archaeological site showing Pozo 1, the test pit excavated by Manzanilla López and colleagues (1991), and Unit 1, excavated by the present authors (map adapted from Barba et al. 1989).

classification, which since Brush's time has become the standard method used by archaeologists in Mesoamerica. Brush, in contrast, analyzed his collection using single attributes, a classification method that was never widely used by Mesoamerican ceramic analysts. In the case of "Pox Pottery" the salient attribute is a particular surface finish of vessel interiors, which Brush observed on vessel body potsherds, the most abundant type of potsherd in his small Early Formative collection. We analyzed potsherds from vessel rims, necks, and bases but did not systematically include body sherds in the statistical study. However, we did observe body sherds during the initial sorting of ceramics.

Our Early Formative ceramic assemblages for the two sites are exceedingly unequal in size. We recorded only 15 potsherds from Puerto Marqués (Table 1) compared to 516 potsherds from $\mathrm{La}$ Zanja (Table 2). The vast majority of studied potsherds from both sites belong to established ceramic types (see Cabrera Guerrero 1990; Ekholm 1948; Manzanilla López et al. 1991). Gómez, Kennett, and Voorhies (2011) also briefly describe these established types, along with several newly defined ceramic types from the La Zanja collection.

Potsherd frequencies by ceramic type and excavation level in Unit 1, Puerto Marqués, are shown in Table 1. The deposits lying between 120 and $300 \mathrm{~cm}$ date to the Middle Formative period (Strata 2-4), whereas those lying between 300 and $400 \mathrm{~cm}$ (Strata 5 and 6) are Early Formative in age. Late Formative period potsherds are evident in low frequency in the uppermost Middle Formative levels $(120-140 \mathrm{~cm})$ and mark a poorly defined transition that is truncated by the uppermost disturbed deposits. The three potsherds in the Archaic period deposits, which we think are intrusive, are also tabulated. The majority of sherds in the very small 


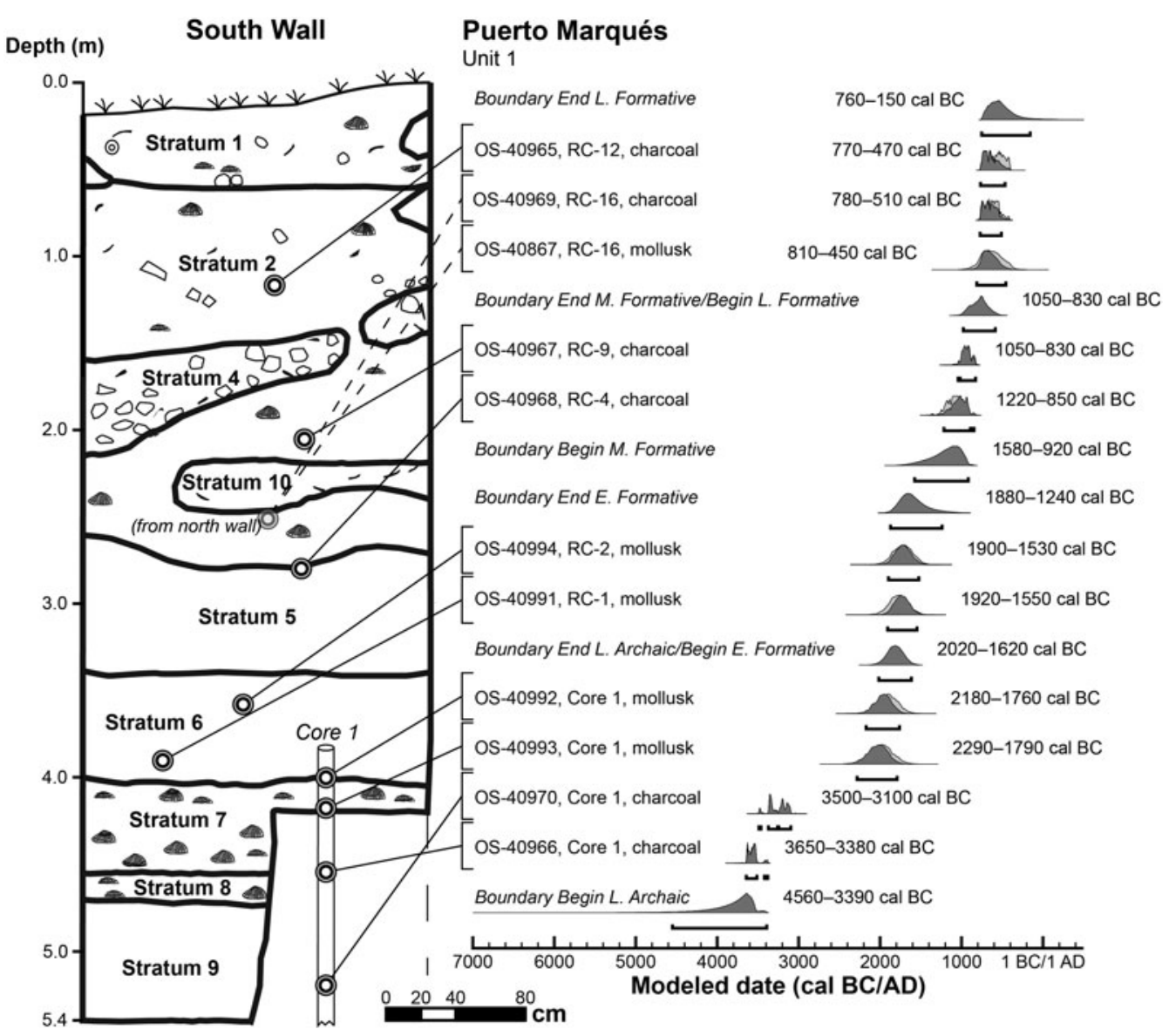

Figure 4. South wall of Unit 1 at Puerto Marqués showing strata and position of radiocarbon samples. Graph of modeled dates is shown on the right (drawn by Barbara Voorhies and Thomas Harper).

collection that dates to the Early Formative period $(n=15)$ belong to the Acapulco Red ceramic type. Six of these had the characteristic "pox" attribute (40\%). Potsherd frequencies by ceramic type and excavation level in Unit $1, \mathrm{La}$ Zanja, are shown in Table 2. The deposits between 60 and $220 \mathrm{~cm}$ (Strata II-V) date to the Middle Formative period, whereas those between 220 and $360 \mathrm{~cm}$ (Stratum VI) are Early Formative in age. We observed the "pox" attribute, tabulated in parentheses in Table 2, in some of these Early Formative period potsherds $(n=22 ; \sim 4 \%)$, but this attribute occurs less frequently in the earliest Middle Formative period assemblage $(n=3$; $\sim 0.4 \%$ ). These percentages are consistent with observations of the "pox" attribute in body sherds examined when the ceramics were originally sorted (Kennett et al. 2006).
Acapulco Red, Acapulco Plain, and Red Slipped wares are the main ceramic types present in the Early Formative period levels (300-360 $\mathrm{cm})$ at Puerto Marqués, but as mentioned the sample is small $(n=15)$. Twelve of the 15 sherds are Acapulco Red wares, and of these, 6 exhibit the "pox" attribute. Necked jars (60\%) and bowls (25\%) dominate the assemblage, and tecomates are rare $(6 \%)$. La Zanja offers a clearer view of Early Formative period ceramic types. Acapulco Red, Acapulco Plain, Brown ware, and Red Slipped are the most abundant ceramic types in the Early Formative period deposits. Icacos Orange also occurs throughout the Early Formative period deposits but is most abundant near the transition to the Middle Formative. These types coincide with the descriptions of Early Formative ceramic assemblages made by Brush 


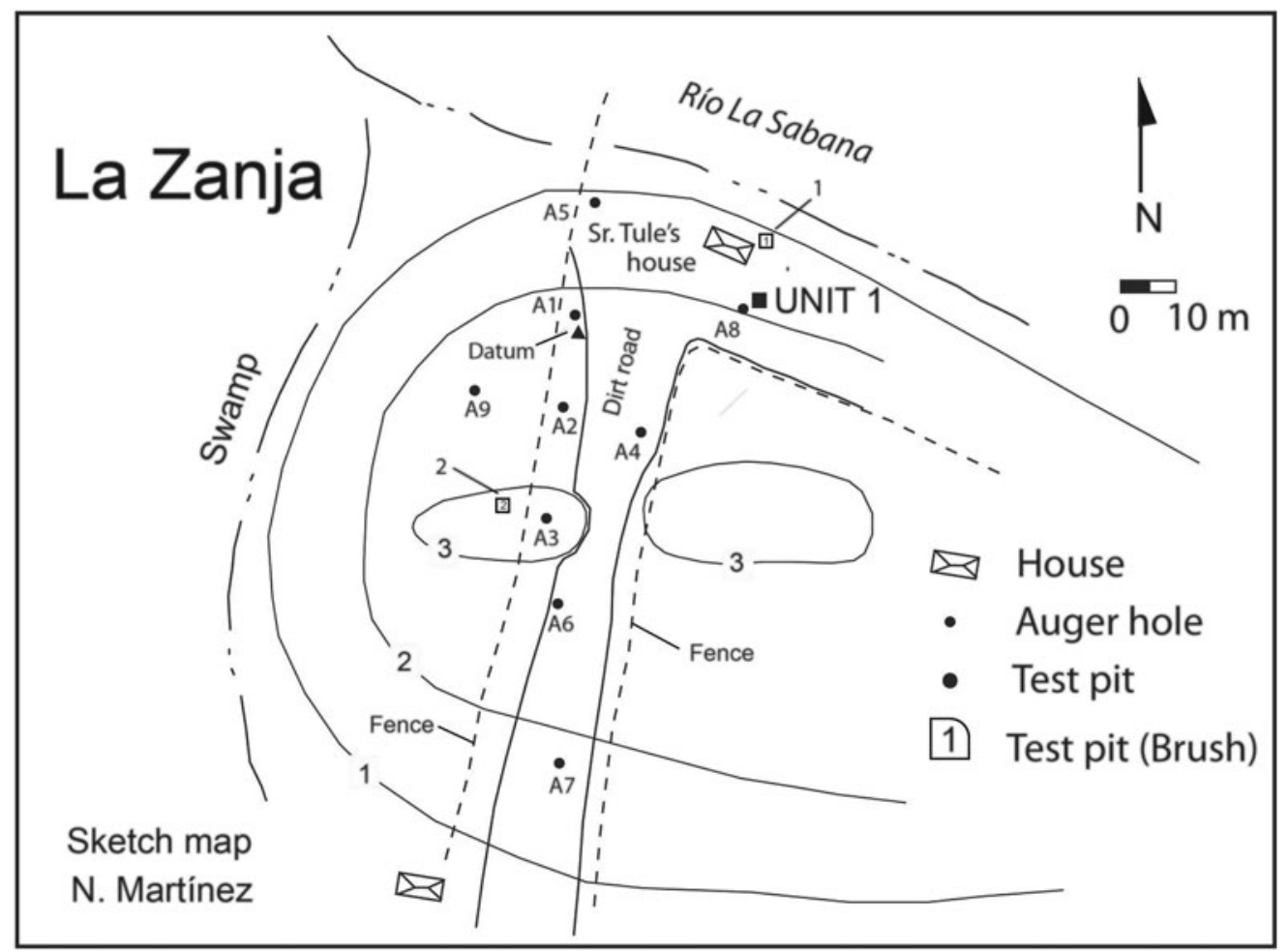

Figure 5. Sketch map of the La Zanja mound showing the locations of Brush's test pits and Unit 1 excavated by Douglas J. Kennett (sketch map by Natalia Martínez and drafted by Douglas J. Kennett).

(1969:57-58), but he emphasized the "pox" attribute, which occurs only in a small number of Acapulco Red, Red Slip, White Polished, Icacos Red on White, Tabares Brown, Sabana Black, Acapulco Red, and Icacos Brown sherds. The "pox" attribute is seen most commonly in Acapulco Red, which concurs with Voorhies's observation of sherds from Brush's collection that is curated in the INAH Ceramoteca in Mexico City. Acapulco Red vessel forms include tecomates (5\%), small mouth jars with vertical necks and direct or slightly outflaring rims $(16 \%)$, and bowls with simple silhouettes and direct, everted, or slightly thickened rims (64\%). Decorative incising occurs on some Acapulco Red vessels, but the fragmentary nature of the assemblage makes it difficult to characterize these decorative features (Figure 6).

Black and White wares mark the transition between the Early and Middle Formative periods at both Puerto Marqués and La Zanja. This decorative combination became widespread in Mesoamerica during the Middle Formative period, along with gray and white wares (Flannery and Marcus 2000). At Puerto Marqués this transition is marked by the appearance of Icacos Red on White and Condesa White and Red wares above $300 \mathrm{~cm}$. Major Middle Formative period vessel forms at Puerto Marqués include jars (54\%), bowls $(23 \%)$, plates $(14 \%)$, and tecomates $(11 \%)$. Black and White wares are more common at La Zanja. These include Caleta White Slip and White Polished wares that occur in greater abundance at and above the transition between the Early and Middle Formative periods (above $260 \mathrm{~cm}$ ). Icacos Red on White and Condesa White and Red occur in low frequencies in the Early Formative deposits at La Zanja: they are most abundant in Middle Formative period deposits above $220 \mathrm{~cm}$ when Sabana Black becomes abundant $(220-280 \mathrm{~cm})$. Sabana Black occurs notably earlier than previously reported for this region (Cabrera Guerrero 1990:107). Major vessel forms include bowls $(66 \%)$, tecomates $(14 \%)$, and plates $(12 \%)$. Jars are present but in very low numbers $(3.6 \%)$. 
Early Formative

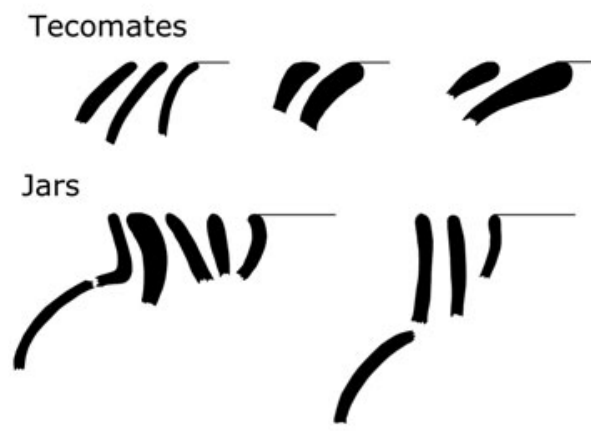

Bowls

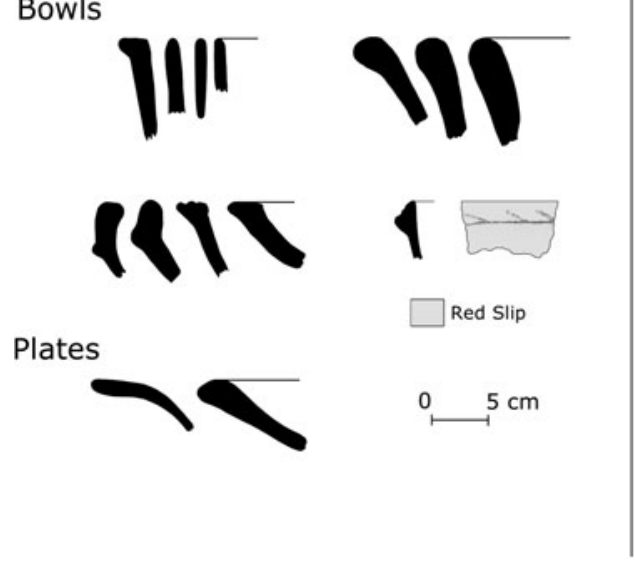

Middle Formative

Tecomates
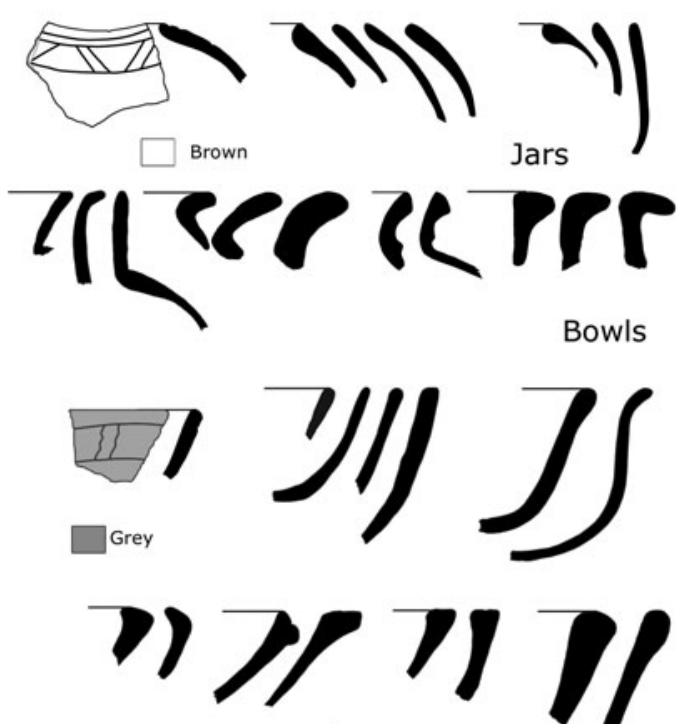

Plates
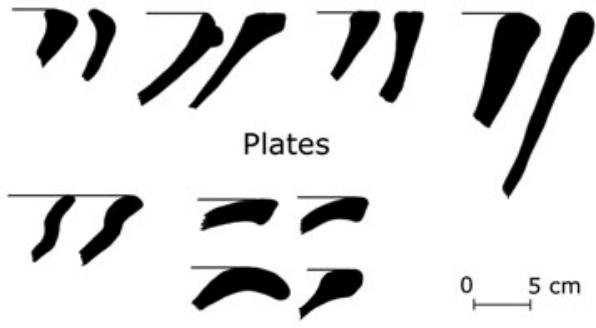

0 $5 \mathrm{~cm}$

Figure 6. Rim profiles of vessel forms dating to the Early and Middle Formative periods (drawn by Josue Gomez).

The Middle to Late Formative period transition was only identified at Puerto Marqués with the appearance of Tambuco Incised and Acapulco Fine Paste in the upper part of Stratum 2 (above $140 \mathrm{~cm}$; see Figure 4) that is truncated by the upper mixed deposits. The appearance of Tambuco Incised and Acapulco Fine Paste correlates with a decline in Condesa White and Red, White Polished, and Icacos Red on White wares in the Middle Formative period deposits at Puerto Marqués.

Overall, ceramics with the pitted interior surfaces primarily occur in Early Formative period deposits as observed by Brush (1969), but this attribute is only found in a small percentage of sherds and in a wide range of pottery types. Therefore, "Pox Pottery" is not a bona fide ceramic type as is often mistakenly supposed, but simply a particular surface finish most commonly found in the interiors of jars and tecomates.

\section{Bayesian Radiocarbon Chronology}

We established a Bayesian chronology for the Early, Middle, and Late Formative period pottery assemblages represented at Puerto Marqués and La Zanja based on 19 radiocarbon dates obtained from the National Ocean Sciences Accelerator Mass Spectrometry (NOSAMS) facility. Charcoal samples collected through each of the sequences were prepared with a series of heated acid-base-acid leaches to remove inorganic carbon and mobile organic acid phases and then were combusted at a high temperature to create $\mathrm{CO}_{2}$. Marine shell samples from the Puerto Marqués sequence were acid-etched with HCL and then directly hydrolyzed with strong acid, $\mathrm{H}_{3} \mathrm{PO}_{4}$, to convert the carbonate to $\mathrm{CO}_{2}$. Gas samples were graphitized and radiocarbon $\left({ }^{14} \mathrm{C}\right)$ concentrations measured using Accelerator Mass Spectrometry. All ${ }^{14} \mathrm{C}$ ages were $\delta^{13} \mathrm{C}$-corrected 
for mass-dependent fractionation with measured ${ }^{13} \mathrm{C} /{ }^{12} \mathrm{C}$ values (Stuiver and Polach 1977) and calibrated using OxCal version 4.4 (Bronk Ramsey 2020) and the IntCal20 northern hemisphere radiocarbon age curve (Reimer et al. 2020). Marine shell dates were calibrated using the Marine20 calibration curve (Heaton et al. 2020). A local marine reservoir correction $(\Delta \mathrm{R})$ was estimated based on a pair of samples from the same context: OS-40969 (charcoal; $2490 \pm 35$ ) and OS-40867 (shell; $3090 \pm 75$ ). Application of a $\Delta \mathrm{R}$ value of $100 \pm 50$ renders the intercept and calibrated age ranges of each of these dates roughly equivalent. The relevant radiocarbon details and results are presented in Table 3.

We established Bayesian chronologies (sensu Kennett et al. 2011) for both Puerto Marqués and La Zanja based on the stratigraphic observations made in the field and the associated radiocarbon dates. Bayesian chronological models are built using the available radiocarbon dates for a site combined with nonquantitative contextual information obtained in the field (e.g., stratigraphic position and artifact assemblages; Kennett et al. 2014). Contextual information provides the framework for constraining probability distributions and the grounds for removing problematic radiocarbon dates. When the modeled distribution completely overlaps with the calibrated date range, there is a good fit between the data and the model. An agreement index (A) provides a measure of fit between the data and model, with values closest to $100 \%$ representing strong concordance. Agreement indices falling below the critical value $\mathrm{A}^{\prime}=60 \%$ indicate a poor fit between the data and the model. This index is used to identify outlier dates or incorrect stratigraphic assumptions (Bronk Ramsey 2009). An agreement index for the overall sequence is also provided for each model (Sequence [Amo$d e l])$. All of the modeling results for Puerto Marqués and La Zanja are discussed later in the article and can be found in the supporting documentation (Supplemental Table 1). Only segments of the Early, Middle, and Late Formative periods are represented at Puerto Marqués and La Zanja, and these do not reflect the age ranges for these periods regionally. The Late Formative period is only represented at Puerto Marqués, but the boundary for the start of these deposits is poorly constrained in our model. 
Table 2. Potsherd Frequency by Ceramic Type and Excavation Level $(\mathrm{cm})$ in Deposits of Unit 1, La Zanja.

\begin{tabular}{|c|c|c|c|c|c|c|c|c|c|c|c|c|c|c|c|c|}
\hline \multirow[b]{2}{*}{ Ceramic Type } & \multicolumn{8}{|c|}{ Middle Formative Period } & \multicolumn{7}{|c|}{ Early Formative Period } & \multirow[b]{2}{*}{ Total } \\
\hline & $60-80$ & $80-100$ & $100-120$ & $120-140$ & $140-160$ & $160-180$ & $180-200$ & $200-220$ & $220-240$ & $240-260$ & $260-280$ & $280-300$ & $300-320$ & $320-340$ & $340-360$ & \\
\hline Red Slip & 0 & 0 & 1 & 1 & 0 & 1 & 3 & 6 & 10 & $18(2)$ & 10 & 2 & 0 & 2 & 1 & 55 \\
\hline White Polished & 0 & 0 & 1 & 3 & 0 & 3 & 4 & 2 & 1 & 3 & 0 & 0 & 0 & $1(1)$ & 0 & 18 \\
\hline Condesa White \& Red & 0 & 1 & 3 & 6 & 0 & 0 & 0 & 3 & 1 & 0 & 1 & 0 & 1 & 0 & 0 & 16 \\
\hline Icacos Red on White & 1 & 0 & 3 & 8 & 0 & 7 & 3 & 1 & 0 & $1(1)$ & 1 & 0 & 0 & 0 & 0 & 25 \\
\hline Caleta White & 0 & 1 & 2 & 15 & 0 & 4 & 4 & 5 & 9 & 8 & 4 & 2 & 0 & 0 & 0 & 54 \\
\hline Tabares Brown & 18 & $21(1)$ & 11 & 24 & 1 & 10 & 10 & 26 & 28 & $28(4)$ & 13 & 19 & 4 & 3 & 0 & 216 \\
\hline Icacos Orange & 0 & 0 & 1 & 0 & 0 & 2 & 2 & 2 & 3 & 12 & 4 & 5 & 3 & 3 & 0 & 37 \\
\hline Sabana Gray & 1 & 2 & 2 & 7 & 1 & 1 & 4 & 5 & 1 & 3 & 7 & 3 & 3 & 0 & 0 & 40 \\
\hline Sabana Black & 2 & 3 & 4 & 6 & 0 & 4 & 4 & 6 & 19 & 28 & $14(2)$ & 6 & 1 & 2 & 0 & 99 \\
\hline Acapulco Plain & 6 & 12 & 5 & 3 & 0 & 4 & 1 & 4 & 3 & 13 & 9 & 21 & 6 & 6 & 0 & 93 \\
\hline Acapulco Red & 77 & 88 & 36 & 110 & 3 & 39 & $38(1)$ & $27(1)$ & $33(1)$ & $34(2)$ & 13 & 20(4) & $16(4)$ & 11 & 0 & 545 \\
\hline Black \& White & 1 & 0 & 1 & 0 & 1 & 0 & 0 & 1 & 3 & 1 & 0 & 0 & 0 & 0 & 0 & 8 \\
\hline Tambuco Incised & 0 & 2 & 2 & 0 & 0 & 0 & 1 & 0 & 0 & 0 & 0 & 0 & 0 & 0 & 0 & 5 \\
\hline Polished Brown & 1 & 4 & 1 & 3 & 0 & 2 & 2 & 1 & 0 & 2 & 3 & 1 & 1 & 1 & 0 & 22 \\
\hline Unknown & 8 & 15 & 6 & 10 & 0 & 6 & 4 & 1 & 1 & 2 & 2 & 1 & 0 & 0 & 0 & 56 \\
\hline Icacos Brown & 1 & 5 & 1 & 7 & 0 & 1 & 1 & 6 & 8 & 10 & 1 & 3 & 1 & $1(1)$ & 0 & 46 \\
\hline Specular Red & 0 & 0 & 0 & 0 & 0 & 0 & 0 & 0 & 0 & 1 & 0 & 0 & 0 & 0 & 0 & $\mathbf{1}$ \\
\hline Total & 116 & 154 & 80 & 203 & 6 & 84 & 81 & 96 & 120 & 164 & 82 & 83 & 36 & 30 & 1 & 1,336 \\
\hline
\end{tabular}

Note: The number of potsherds with the "pox" attribute is shown in parentheses. 
Table 3. Radiocarbon Samples and their Results for the Archaeological Sites of La Zanja and Puerto Marqués.

\begin{tabular}{|c|c|c|c|c|c|c|c|}
\hline Provenience & Lab Number & Material & ${ }^{14} \mathrm{C}$ Age (BP) & \pm & $\begin{array}{c}\mathrm{cal} B C / A D \\
(\mu)\end{array}$ & $\begin{array}{c}\text { cal BC/AD } \\
(2 \sigma \text { low })\end{array}$ & $\begin{array}{c}\text { cal BC/AD } \\
(2 \sigma \text { high })\end{array}$ \\
\hline \multicolumn{8}{|c|}{ La Zanja Early Formative (3.60-2.20 m) } \\
\hline La Zanja, Uniti 1, RC-20, $320 \mathrm{~cm}$ & OS-40961 & Charcoal & 3030 & 40 & -1280 & -1410 & -1130 \\
\hline La Zanja, Unit 1, RC-1, $215 \mathrm{~cm}$ & OS-40962 & Charcoal & 3010 & 40 & -1250 & -1400 & -1120 \\
\hline La Zanja, Unit 1, RC-5, $245 \mathrm{~cm}$ & OS-41342 & Charcoal & 2890 & 30 & -1070 & -1200 & -970 \\
\hline \multicolumn{8}{|c|}{ La Zanja Middle Formative $(2.00-0.60 \mathrm{~m})$} \\
\hline La Zanja, Unit 1, RC-7, $106 \mathrm{~cm}$ & OS-40964 & Charcoal & 2720 & 40 & -870 & -970 & -800 \\
\hline La Zanja, Unit 1, RC-2, $210 \mathrm{~cm}$ & OS-40865 & Charcoal & 2540 & 40 & -670 & -810 & -530 \\
\hline La Zanja, Unit 1, RC-4, $150 \mathrm{~cm}$ & OS-40963 & Charcoal & 2520 & 35 & -660 & -800 & -530 \\
\hline La Zanja, Unit 1, RC-15, $63 \mathrm{~cm}$ & OS-41343 & Charcoal & 2510 & 30 & -650 & -790 & -530 \\
\hline \multicolumn{8}{|c|}{ Puerto Marqués Late Archaic (4.00-5.40 m) } \\
\hline Puerto Marqués, Core 1, 80-95 & OS-40966 & Charcoal & 4800 & 40 & -3570 & -3660 & -3380 \\
\hline Puerto Marqués, Core 1, 192 & OS-40970 & Charcoal & 4560 & 40 & -3250 & -3490 & -3100 \\
\hline Puerto Marqués, Core $1,40 \mathrm{~cm}$ & OS-40993 & Mollusk & 4180 & 70 & -1980 & -2230 & -1730 \\
\hline Puerto Marqués, Core $1,20 \mathrm{~cm}$ & OS-40992 & Mollusk & 4120 & 45 & -1900 & -2110 & -1710 \\
\hline \multicolumn{8}{|c|}{ Puerto Marqués Early Formative $(3.00-4.00 \mathrm{~m})$} \\
\hline Puerto Marqués, Unit 1, RC-1 & OS-40991 & Mollusk & 4020 & 45 & -1770 & -1960 & -1590 \\
\hline Puerto Marqués, Unit 1, RC-2 & OS-40994 & Mollusk & 3980 & 50 & -1720 & -1910 & -1520 \\
\hline \multicolumn{8}{|c|}{ Puerto Marqués Middle Formative $(1.20-3.00 \mathrm{~m})$} \\
\hline Puerto Marqués, Unit 1, RC-4 & OS-40968 & Charcoal & 2890 & 65 & -1080 & -1260 & -900 \\
\hline Puerto Marqués, Unit 1, RC-9 & OS-40967 & Charcoal & 2790 & 40 & -940 & -1050 & -830 \\
\hline \multicolumn{8}{|c|}{ Puerto Marqués Late Formative $(0.60-1.20 \mathrm{~m})$} \\
\hline Puerto Marqués, Unit 1, RC-16 & OS-40867 & Mollusk & 3090 & 75 & -630 & -830 & -390 \\
\hline Puerto Marqués, Unit 1, RC-16 & OS-40969 & Charcoal & 2490 & 35 & -630 & -790 & -480 \\
\hline Puerto Marqués, Unit 1, RC-12 & OS-40965 & Charcoal & 2460 & 40 & -600 & -760 & -410 \\
\hline
\end{tabular}

Figure 4 shows the chronostratigraphic model for Puerto Marqués. In this figure, the light-gray probability distributions represent calibrated date ranges without model constraints. The dark-gray distribution shows these probability estimates trimmed or shifted based on the constraints of the stratigraphic model. Modeled distributions were established for deposits at Puerto Marqués dating to the Late Archaic (3890-1820 cal BC), Early Formative (1820-1400 cal BC), Middle Formative (1000-770 cal BC), and the transition to the earliest part of the Late Formative (770-150 cal BC). The beginning and end of each period are represented by the mean $(\mu)$ of the modeled phase boundaries that bracket each interval (see Supplemental Table 1) and are conservative estimates for the length of these periods represented at Puerto Marqués. The sequence is not continuous, and the model reflects a substantial hiatus in the Early Formative period (see the later discussion). No outliers were detected, and the agreement indices for the sequence (Amodel $=115.5$ ) and the overall model (Aoverall $=108.4$ ) indicate strong corroboration with the radiocarbon data.
The earliest Acapulco Red sherds at Puerto Marqués, some with the "pox" attribute, occur in the upper portion of Stratum 6 and into Stratum 5 and date to the Early Formative between 1820 and $1400 \mathrm{cal}$ BC. These Early Formative sherds are directly associated with a radiocarbon date (OS-40991) with a 2-sigma range between 1900 and $1530 \mathrm{cal}$ BC (a mean age of $1720 \mathrm{cal}$ BC). A gap in the radiocarbon record occurs between 1400 and $1000 \mathrm{cal} \mathrm{BC}$ and the appearance of Middle Formative period White wares (Icacos Red on White and Condesa White and Red wares above $300 \mathrm{~cm}$ ) in Strata 2-4 dating between 1000 and $770 \mathrm{cal}$ BC. Middle Formative White Wares decline in frequency in the upper portion of Stratum $2(140-120 \mathrm{~cm})$ with the first appearance of Late Formative period ceramics (Tambuco Incised and Acapulco Fine Paste) at some time between 770 and 150 cal BC. Levels above $120 \mathrm{~cm}$ (Stratum 1) were highly disturbed and contained a mixture of modern and prehistoric materials that occurred when the modern terrace that truncated Brush's original section was cut. 


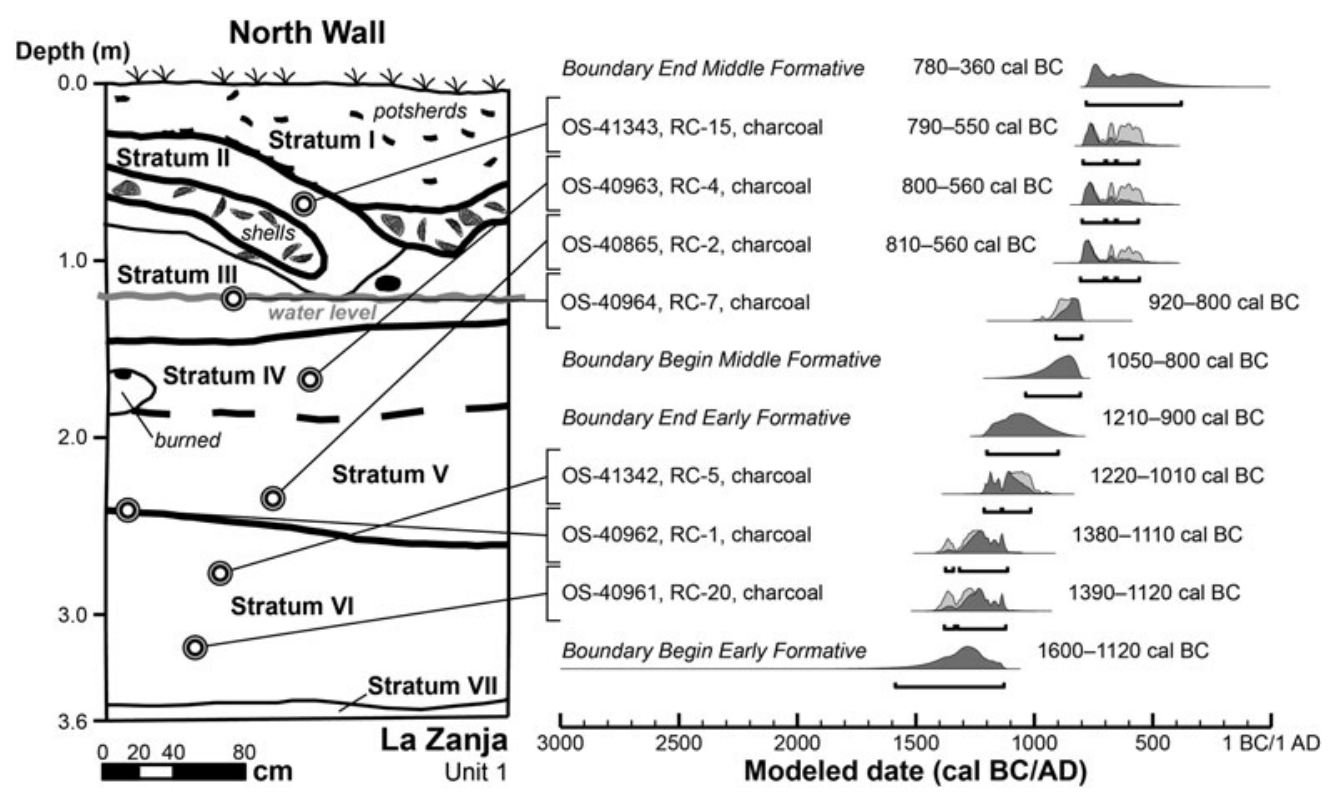

Figure 7. Profile of the north wall of Unit 1 at La Zanja showing strata and position of radiocarbon samples. Graph of modeled dates is shown on the right (drawn by Douglas J. Kennett and Thomas Harper).

The chronostratigraphic model for La Zanja is shown in Figure 7. A Bayesian chronological model was established for the Early and Middle Formative periods based on a sequence of seven radiocarbon dates. Formative period deposits between 220 and $360 \mathrm{~cm}$ (Stratum VI) date to 1330-1060 cal BC. The earliest Early Formative sherds, some with the "pox" attribute, are directly associated with a radiocarbon date (OS-40991), with a 2-sigma range between 1390 and $1120 \mathrm{cal} \mathrm{BC}$ (a mean age of $1240 \mathrm{cal}$ BC). The upper Middle Formative period deposits $(60-220 \mathrm{~cm}$, Strata II-V) date to $900-600 \mathrm{cal}$ $\mathrm{BC}$. The sequence appears to be relatively continuous, with no obvious gaps in the record. Reversals occur within the Early and Middle Formative period deposits, but no outliers were removed from the model. Agreement indices for the sequence (Amodel $=91.8$ ) and the overall model (Aoverall $=90.1$ ) indicate strong corroboration between the phased model and the chronostratigraphic data.

The Early Formative period ceramic assemblage at La Zanja is larger $(n=516)$ and covers a period of time (1330-1060 cal BC) that is not well represented at Puerto Marqués. Ceramic types predominantly found in Stratum
VI $(220-360 \mathrm{~cm})$ include Red Slip, Taberas Brown, Icacos Orange, Sabana Gray, Sabana Black, Acapulco Plain, Acapulco Red, and Icacos Brown wares. The "pox" attribute occurs in low frequency $(n=20 ; 3.9 \%)$ in Red Slip, Tabera Brown, Sabana Black, and Icacos Brown, but is most common in Acapulco Red wares (8.7\%). White and Black wares appear in the uppermost Early Formative period levels $(220-280 \mathrm{~cm})$ but are more abundant in Middle Formative period strata (II-V; 60-220 cm) dating between 900 and $600 \mathrm{cal} \mathrm{BC}$. These wares include White Polished, Condesa White on Red, Icacos Red on White, Caleta White, Sabana Black, and Black on White. Taberas Brown and Acapulco Red wares persist throughout the Middle Formative period deposits, and a small number have the "pox" attribute $(n=3 ; \sim 0.4 \%)$.

\section{Discussion and Conclusions}

"Pox Pottery" continues to be cited in textbooks as the earliest pottery in Mesoamerica despite questions regarding its stratigraphic association and the accuracy of the single radiocarbon date of 2440 BC. Here we demonstrate that 
Acapulco Red ceramics at Puerto Marqués, some with the "pox" attribute, date between 1820 and $1400 \mathrm{cal}$ BC. The assemblage of these early ceramics is small and dominated by globular necked jars and gourd-shaped tecomates. A wider range of ceramic types and vessel forms (necked jars, bowls, and tecomates) occur in Early Formative period deposits at La Zanja dating from 1330 to 1060 cal BC; a small percentage of these, most notably Acapulco Red wares, have the "pox" attribute. The Middle Formative period is marked by the appearance of Black and White wares, and the "pox" attribute is uncommon in these later assemblages. We argue that pottery on the Guerrero coast did not occur as early as originally thought and that "pox" is not a ceramic type. We agree with Brush (1965) that this attribute resulted from the removal of coarse-grained sand temper during the production process.

The earliest Acapulco Red wares (1820-1400 cal BC) from coastal Guerrero are stylistically similar to other Red-on-Buff traditions west of the Isthmus of Tehuantepec and the Central Mexican Highlands (Flannery and Marcus 1994; Hepp 2019; Winter 1992). They are similar in character to pottery from Espiridión/Tierras Largas in highland Oaxaca dating to $1900-1500 \mathrm{cal} \mathrm{BC}$ and to Tlacuache pottery from coastal Oaxaca dating to 1950-1530 cal BC (Hepp 2019). There are also similarities with Purrón Pottery from the Tehuacan Valley (García Cook and Merino Carrión 2005; Hepp 2019; Johnson and MacNeish 1972), which is poorly dated but likely dates to 1900-1680 cal BC. Acapulco Red wares are distinctive from the gourd-inspired and finely made thin-walled Barra Phase ceramics from coastal Chiapas, Mexico, dating to 1900-1700 cal BC (Blake and Clark 1993), Ojochi pottery from the Mexico's Gulf Coast dating to 1750 $1550 \mathrm{cal}$ BC (Arnold 2003), and Barahona ceramics from northern Honduras dating to 1600-1400 cal BC (Joyce and Henderson 2001). Some specimens with specular red slip appear to have been imported from the Soconusco area, whereas others with white slip seem to have originated elsewhere, suggesting a high level of contact and exchange between culturally distinct regions.

Hepp (2019) has suggested that an early Red-on-Buff ceramic tradition developed west of the Isthmus of Tehuantepec and in the Central Mexican Highlands in parallel with the distinctive Locona tradition (Barra, Locona) in coastal Chiapas that extended across the Isthmus of Tehuantepec to the Gulf Coast (Ojochi pottery). The age and character of the Red-on-Buff pottery from coastal Guerrero described here are consistent with this idea. Three contemporary and distinct ceramic traditions-Red-on-Buff, Locona, and Barahona - in Mesoamerica dating between 1900 and 1400 cal BC suggest either (1) differential local adoption during the rapid transmission of ceramic technology ("dependent invention"; Clark and Gosser 1995) from earlier Central and South America traditions or (2) an independent origin of ceramic technology (Hepp 2019). Hepp (2019) has argued for at least two distinct networks of interregional interaction and possibly cultural or linguistic divisions based on the distribution of Red-on-Buff ceramics, the dominance of obsidian from Central Mexican sources, and the absence of Central American sources in coastal Oaxaca. The presence of contemporary Red-on-Buff ceramics in coastal Guerrero, combined with obsidian exclusively from Central Mexican sources (Ucareo, Paredon, and Otumba; Ebert et al. 2014), is consistent with this hypothesis.

Overall, the earliest Acapulco Red wares from coastal Guerrero, some with the "pox" attribute, remain among the earliest ceramic traditions in Mesoamerica. Our results help constrain the early age (1900-1400 cal BC) and geographic extent of Red-on-Buff ceramic traditions west of the Isthmus of Tehuantepec and into the Central Mexican Highlands. Future excavations and high-resolution chronological work in Mexico and Central America will be required to determine whether ceramic technology has an independent origin in Mexico or was adopted rapidly as it dispersed northward out of South America.

Acknowledgments. This work was supported by the National Science Foundation under Grant IBCS-02112215 and carried out with permission from the Consejo de Arqueología, Instituto Nacional de Antropología e Historia, Mexico. We thank Arqlgo. Cuautémoc Reyes Alvarez (Centro Regional de Guerrero, Instituto Nacional de Antropología e Historia) for facilitating our research; Dr. Rubén Manzanilla López for generously sharing insights about the prehistory of Puerto 
Marqués; and Lic. Martha E. Cabrera Guerrero for her environmental and archaeological knowledge of the region. Ing. Paul Rangel Merkley kindly provided access to the Puerto Marqués site, whereas Ing. Victor Hugo Martínez and Ing. Francisco Rodríguez from Desarrollo Integral de Ingenería SAdeCV aided the project in innumerable ways. Barbara Voorhies oversaw excavations at Puerto Marqués, and Douglas Kennett supervised the La Zanja excavations. Josue Gomez conducted the ceramic analysis, and Kennett developed the site chronology with assistance from Thomas Harper. We extend special thanks to our able archaeology field crew: Cassandra Albush, Natalia Martínez Tagueña, Juan Jorge Morales, Amparo Robles Salmerón, Cameron M. Walker, and Nathan Wilson. Thomas Harper assisted with the graphics. Finally, our immense gratitude to John E. Clark, former director of the New World Archaeological Foundation, Brigham Young University, for lending us field vehicles, field equipment, and workspace for postfieldwork analyses.

Data Availability Statement. All data required to replicate this study are provided in the supplemental materials.

Supplemental Materials. For supplemental material accompanying this article, visit https://doi.org/10.1017/laq.2021.14.

Supplemental Table 1. Bayesian Modeling Results for Puerto Marqués and La Zanja.

\section{Notes}

1. Brush uses the term "Early Preclassic period."

2. Brush (1969:Figure 1) refers to this lagoon as Laguna de Nahuala.

\section{References Cited}

Arnold, Philip, III

2003 Early Formative Pottery from the Tuxtla Mountains and Implications for Gulf Coast Olmec Origins. Latin American Antiquity 14:29-46.

Barba, Luis, Guillermo Pérez, Elizabeth Mejía, and Eliseo Linares

1989 Estudio del sitio Punta Diamante, Acapulco, utilizando técnicas de prospección arqueológica. IIA-UNAM, Mexico City.

Blake, Michael, and John E. Clark

1993 The Power of Prestige: Competitive Generosity and the Emergence of Rank Societies in Lowland Mesoamerica. In Factional Competition and Political Development in the New World, edited by Elizabeth M. Brumfiel and John W. Fox, pp. 17-30. Cambridge University Press, Cambridge.

Bronk Ramsey, Christopher

2009 Dealing with Outliers and Offsets in Radiocarbon Dating. Radiocarbon 51:1023-1045.

2020 OxCal 4.4 Manual. Electronic document, https://c14. arch.ox.ac.uk/oxcalhelp/hlp_contents.html, accessed October 20, 2020.

Brush, Charles F.

1965 Pox Pottery: Earliest Identified Mexican Ceramic. Science 149:194-195.
1969 A Contribution to the Archeology of Coastal Guerrero, Mexico. PhD dissertation, Department of Anthropology, Columbia University, New York.

Cabrera Guerrero, Martha Eugenia

1990 Los pobladoes prehispánicos de Acapulco. Serie Arqueología, Instituto Nacional de Antropología e Historia, Mexico City.

Clark, John E., and Dennis Gosser

1995 Reinventing Mesoamerica's First Pottery. In The Emergence of Pottery: Technology and Innovation in Ancient Societies, edited by William K. Barnett and John W. Hoopes, pp. 209-221. Smithsonian Institution, Washington, DC.

Ebert, Claire E., Mark Dennison, Kenneth G. Hirth, Sarah B. McClure, and Douglas J. Kennett

2014 Formative Period Obsidian Exchange along the Pacific Coast of Mesoamerica. Archaeometry 57:54-74.

Ekholm, Gordon F.

1948 Ceramic Stratigraphy at Acapulco, Guerrero. In El occidente de México, Vol. IV, pp. 95-104. Mesa Redonda de la Sociedad Mexicana de Antropología, Mexico City.

Flannery, Kent V., and Joyce Marcus

1994 Early Formative Pottery of the Valley of Oaxaca, Mexico. Memoirs of the Museum of Anthropology No. 27. University of Michigan, Ann Arbor.

2000 Formative Mexican Chiefdoms and the Myth of the "Mother Culture." Journal of Anthropological Archaeology 19:1-37.

García Cook, Ángel, and Beatriz Leonor Merino Carrión

$2005 \mathrm{El}$ inicio de la producción alfarera en México. In $L a$ producción alfarera en el México Antiguo I, edited by Beatriz Leonor Merino Carrión and Ángel García Cook, pp. 73-119. Instituto Nacional de Antropología e Historia, Mexico City.

Gomez, Josue, Douglas J. Kennett, and Barbara Voorhies

2011 Reconsidering Pox Pottery: Early Ceramics from Coastal Guerrero. Poster presented at the 76th Annual Meeting of the Society for American Archaeology, Sacramento, California.

Heaton, Timothy J., Peter Köhler, Martin Butzin, Edouard Bard, Ron W. Reimer, William E. N. Austin, Christopher Bronk Ramsey, Pieter Grootes, Konrad A. Hughen, Bernd Kromer, Paula J. Reimer, Jess Adkins, Andrea Burke, Mea S. Cook, Jesper Olsen, and Luke C. Skinner 2020 Marine20 - The Marine Radiocarbon Age Calibration Curve (0-55,000 cal BP). Radiocarbon 62:779820. DOI:10.1017/RDC.2020.68.

Hepp, Guy David

2019 Interaction and Exchange in Early Formative Western Central Mesoamerica: New Data from Coastal Oaxaca. In Interregional Interaction in Ancient Mesoamerica, edited by Joshua D. Englehardt and Michael D. Carrasco, pp. 51-82. University Press of Colorado, Boulder.

Johnson, Frederick, and Richard S. MacNeish

1972 Chronometric Dating. In The Prehistory of the Tehuacan Valley, Vol. 4: Chronology and Irrigation, edited by Frederick Johnson, pp. 3-55. University of Texas Press, Austin.

Joyce, Rosemary A., and John S. Henderson

2001 Beginnings of Village Life in Eastern Mesoamerica. Latin American Antiquity 12:50-24.

Kennett, Douglas J., Brendan J. Culleton, Jamie Dexter, Scott Mensing, and David H. Thomas

2014 High Precision AMS ${ }^{14} \mathrm{C}$ Chronology for Gatecliff 
Rockshelter, Nevada. Journal of Archaeological Science 52:621-632.

Kennett, Douglas J., Brendan J. Culleton, Barbara Voorhies, and John R. Southon

2011 Bayesian Analysis of High Precision AMS ${ }^{14} \mathrm{C}$ Dates from a Prehistoric Mexican Shellmound. Radiocarbon 53:101-116.

Kennett, Douglas J., Barbara Voorhies, José Iriarte, Dolores Piperno, and Thomas A. Wake

2006 Tercer y final informe técnico del Proyecto ArcaicoFormativo: Costa de Guerrero (Temporada 2003). Manuscript on file, Instituto Nacional de Antropología e Historia, Mexico City.

Kennett, Douglas J., Barbara Voorhies, Thomas Wake, and Natalia Martínez

2008 Long-Term Effects of Human Predation on Marine Ecosystems in Guerrero, Mexico. In Human Impacts on Marine Environments, edited by Torben C. Rick and Jon M. Erlandson, pp. 103-124. University of California Press, Berkeley.

MacNeish, Richard S.

1964 Ancient Mesoamerican Civilization. Science 142:531-537.

Manzanilla López, Rubén

2000 La región arqueológica de la Costa Grande de Guerrero: Su definición a través de la organización social y territorialidad prehispánicas. $\mathrm{PhD}$ dissertation, Escuela Nacional de Antropología e Historia, Mexico City.

Manzanilla López, Rubén, Arturo Talavera González, and Ernesto Rodriguez Sánchez

1991 Informe técnico de campo de la primera etapa del Proyecto de Investigación y Salvamento Arqueológico en Puerto Marqués, estado de Guerrero. Technical Report. Archives of the Instituto Nacional de Antropología e Historia, Mexico City.

Reimer, Paula J., William E. N. Austin, Edouard Bard, Alex Bayliss, Paul G. Blackwell, Christopher Bronk Ramsey,
Martin Butzin, Hai Cheng, R. Lawrence Edwards, Michael Friedrich, Pieter M. Grootes, Thomas P. Guilderson, Irka Hajdas, Timothy J. Heaton, Alan G. Hogg, Konrad A. Hughen, Bernd Kromer, Sturt W. Manning, Raimund Muscheler, Jonathan G. Palmer, Charlotte Pearson, Johannes van der Plicht, Ron W. Reimer, David A. Richards, E. Marian Scott, John R. Southon, Christian S. M. Turney, Lukas Wacker, Florian Adolphi, Ulf Büntgen, Manuela Capano, Simon Fahrni, Alexandra Fogtmann-Schulz, Ronny Friedrich, Peter Köhler, Sabrina Kudsk, Fusa Miyake, Jesper Olsen, Frederick Reinig, Minoru Sakamoto, Adam Sookdeo, and Sahra Talamo

2020 The IntCal20 Northern Hemisphere Radiocarbon Age Calibration Curve (0-55 cal kBP). Radiocarbon 62:725-757. DOI:10.1017/RDC.2020.41.

Stuiver, Minze, and Henry A. Polach,

1977 Discussion Reporting of ${ }^{14} \mathrm{C}$ Data. Radiocarbon 19:355-363.

Voorhies, Barbara, and Douglas J. Kennett

2016 Reanalizando el "Pox Pottery" de la Costa de Guerrero. In El conocimiento antropológico e histórico sobre Guerrero: Reflexiones sobre la investigación multidisciplinaria e integral y su impacto social, Vol. 3, edited by Rosa María Reyna Robles, pp. 25-34. Instituto Nacional de Antropología e Historia, Mexico City.

2021 Preceramic Lifeways on the Mesoamerican South Pacific Coast. In Preceramic Mesoamerica, edited by Aleksander Borejsza, Arthur A. Joyce, and Jon C. Lohse. Routledge Press, London, in press.

Winter, Marcus

1992 Oaxaca: The Archaeological Record. Minutiae Mexicano, Mexico City.

Submitted August 13, 2020; Revised December 12, 2020; Accepted January 28, 2021 